\title{
Genetic Analysis of the Mitochondrial rrnS Gene of Zoonotic Anisakis pegreffii (Nematoda: Anisakidae) Isolated from Micromesistius poutassou (R.) in the Aegean Sea
}

\author{
Gökmen Zafer PEKMEZCI
}

Department of Aquatic Animal Diseases, Faculty of Veterinary Medicine, University of Ondokuz Mayis, Samsun, Turkey

How to cite: Pekmezci, G.Z. (2021). Genetic Analysis of the Mitochondrial rrnS Gene of Zoonotic Anisakis pegreffii (Nematoda: Anisakidae) Isolated from Micromesistius poutassou (R.) in the Aegean Sea. J. Anatolian Env. and Anim. Sciences, 6(2), 266-269.

Atıf yapmak için: Pekmezci, G.Z. (2021). Ege Denizi'ndeki Micromesistius poutassou'dan (R.) İzole Edilen Zoonotik Anisakis pegreffii'nin (Nematoda: Anisakidae) Mitokondriyal rrnS Geninin Genetik Analizi. Anadolu Çev. ve Hay. Dergisi, 6(2), 266-269.

\begin{abstract}
Ascaridoid nematodes were found in viscera of the blue whiting Micromesistius poutassou (Risso, 1826) from the Aegean Sea in the parasitological examination. Collected nematodes were morphologically identified as the third (L3) stage of Anisakis type I larvae and then subject to Restriction Fragment Length Polymorphism (RFLP) analysis of the internal transcribed spacer (ITS) region to identify the species. Randomly selected larvae were molecularly confirmed as Anisakis pegreffii by RFLP analysis. Subsequently, L3 of A. pegreffii were amplified and bi-directionally sequenced at the small subunit ribosomal RNA (rrnS) gene. The $r r n S$ sequence of $A$. pegreffii (MT484284) had 100\% identity with the $r r n S$ gene of $A$. pegreffii (JX500050, LC222461, MF140359, MT312511, MT312512) which were found in fish and cetaceans hosts, Scomber japonicus, Conger myriaster, Neophocaena asiaeorientalis, and Stenella coeruleoalba, from the Mediterranean Sea, Japanese, Chinese, and Korean waters, respectively. This study provided the genetic analysis of zoonotic A. pegreffii from the Turkish marine waters based on the $r r n S$ gene for the first time. This sequence (MT484284) can be used as the novel $r r n S$ sequence of $A$. pegreffii in the genetic analysis for ascaridoid nematodes in the Mediterranean Sea.
\end{abstract}

Keywords: Anisakis pegreffii, molecular characterization, mtDNA, $r r n S$ gene, Turkish coast.

\section{Ege Denizi'ndeki Micromesistius poutassou'dan (R.) İzole Edilen Zoonotik Anisakis pegreffii'nin (Nematoda: Anisakidae) Mitokondriyal rrnS Geninin Genetik Analizi}

*Corresponding author's: Gökmen Zafer PEKMEZCI Department of Aquatic Animal Diseases, Faculty of Veterinary Medicine, Unis 凶: zpekmezci@omu.edu.tr
Öz: Parazitolojik incelemede Ege Denizi'nden mavi mezgit Micromesistius poutassou (Risso, 1826) balığının iç organlarında askaridoid nematodlar bulundu. Toplanan nematodlar morfolojik olarak üçüncü (L3) dönem Anisakis tip I larva olarak tanımlandı ve daha sonra türleri tanımlamak için internal transcribed spacer (ITS) bölgesi Restriksiyon Parça Uzunluk Polimorfizm (RFLP) analizlerine tabi tutuldu. Rastgele seçilen larvalar RFLP analizleri ile Anisakis pegreffii olarak doğrulandı. Daha sonra $A$. pegreffii'nin L3'ünün küçük alt birim ribozomal RNA $(r r n S)$ geni çoğaltıldı ve iki yönlü olarak sekanslandı. Anisakis pegreffii'nin rrnS sekans1 (MT484284) Akdeniz, Japon, Çin ve Kore sularından Scomber japonicus, Congenaer asyager, Neophocaena asiaeorientalis ve Stenella coeruleoalba gibi balık ve deniz memelilerinde bulunan $A$. pegreffii'nin rrnS geni (JX500050, LC222461, MF140359, MT312511, MT312512) ile \%100 benzerliğe sahipti. Bu çalışma ilk kez Türk deniz sularından zoonotik A. pegreffii'nin $r r n S$ genine dayalı genetik analizini sağladı. Bu dizi (MT484284), Akdeniz'deki askaridoid nematodların genetik analizinde $A$. pegreffii'nin yeni $r r n S$ dizisi olarak kullanılabilir.

Anahtar kelimeler: Anisakis pegreffii, moleküler karakterizasyon, mtDNA, $r r n S$ geni, Türk kiyıları. 


\section{INTRODUCTION}

Adult nematodes of Anisakis Dujardin, 1845 are mainly found in the gastrointestinal canal of marine mammals. Different marine mammals and marine fish or squids serve as definite and intermediate or paratenic hosts. Based on molecular genetic markers such as nuclear and mitochondrial DNA, nine distinct Anisakis species have been confirmed worldwide (Mattiucci \& Nassetti, 2008; Mattiucci et al., 2018). Among the mitochondrial genes, the cytochrome oxidase I ( $\operatorname{cox} 1)$, II $(\operatorname{cox} 2)$, and the small ribosomal subunit of RNA ( $r r n S$ ) have been widely used for the genetic analysis of Anisakis species (Mattiucci et al., 2014; Mattiucci et al., 2018; Pekmezci \& Onuk, 2020). Anisakis pegreffii is zoonotic nematodes, and the dominant species in the Mediterranean Sea, widespread in all the fish species (Mattiucci \& Nassetti, 2008; Mattiucci et al., 2018).

Both mitochondrial cox 2 and nuclear ITS data of Anisakis species from marine fish were previously reported from Turkish marine waters (Pekmezci et al., 2014). Moreover, genetic analyses of $r r n S$ loci of Hysterothylacium aduncum, $H$. fabri, Contracaecum overstreeti, and A. typica among ascaridoids nematodes of marine fish were molecularly made from the coast of Turkey (Pekmezci, 2019; Pekmezci \& Yardimci, 2019; Pekmezci \& Onuk, 2020; Simsek et al., 2021). There is no study about the genetic characterization of the mitochondrial $r r n S$ gene of $A$. pegreffii from the Turkish marine waters. Therefore, the molecular characterization of the $r r n S$ gene of $A$. pegreffii from Aegean Sea is aimed for the first time in the current study.

\section{MATERIALS AND METHODS}

Morphological examinations: Nematodes were collected from Micromesistius poutassou (R.) in the Aegean Sea coasts of Turkey. Parasites were individually cut into three parts. The anterior and posterior parts were used for morphological identifications. Nematodes were morphologically identified by light microscope according to Berland, (1961) and Petter \& Maillard, (1988). Morphologically identified three representative specimens were randomly selected and genetically analysed.

PCR, RFLP analysis and DNA sequencing: The middle parts were extracted for genomic DNA (gDNA) using commercial kits. The internal transcribed spacer (ITS) region (ITS1, 5.8S rDNA, ITS2) of nuclear DNA was amplified using polymerase chain reaction (PCR) with NC5/NC2 primers (Zhu et al., 1998) in a final volume of $50 \mu$ as follows: $2 \mathrm{X}$ Hot Start PCR Master Mix, $0.5 \mu \mathrm{M}$ of each primer, and 10-50 ng gDNA. The PCR reactions were subjected to initial denaturation at $95^{\circ} \mathrm{C}$ for $5 \mathrm{~min}$, followed by 30 cycles of $95^{\circ} \mathrm{C}$ for $60 \mathrm{~s}, 55^{\circ} \mathrm{C}$ for $60 \mathrm{~s}, 72^{\circ} \mathrm{C}$ for $60 \mathrm{~s}$, and a final extension at $72^{\circ} \mathrm{C}$ for $10 \mathrm{~min}$. All PCR amplicons were electrophoresed on $1 \%$ gel and visualized under UV illumination. The ITS region was then digested with HhaI and HinfI enzymes using restriction fragment length polymorphism (RFLP) analysis to identify the species (D'Amelio et al., 2000). RFLP patterns were electrophoresed on $1.5 \%$ gel and visualized under UV illumination. The small subunit ribosomal RNA ( $r r n S)$ gene in the mitochondrial DNA of randomly selected three Anisakis species was amplified PCR (D'Amelio et al., 2007). PCR was performed using primers MH3/MH4.5 in a final volume of $50 \mu \mathrm{l}$ as follows: 2X Hot Start PCR Master Mix, and $0.5 \mu \mathrm{M}$ of each primer, and 10-50 ng gDNA. The PCR protocols were $95^{\circ} \mathrm{C}$ for $60 \mathrm{~s}, 55^{\circ} \mathrm{C}$ for $60 \mathrm{~s}, 72^{\circ} \mathrm{C}$ for $60 \mathrm{~s}$ for 30 cycles, and a final extension at $72^{\circ} \mathrm{C}$ for $10 \mathrm{~min}$. PCR amplicons were electrophoresed using a $1.5 \%$ agarose gel. Randomly selected three individuals were purified with a PCR purification kit and sequenced using the MH3/MH4.5 primers with an ABI PRISM 3130xl automatic sequencer using a BigDye Terminator v3.1 Cycle Sequencing kit by Macrogen (Amsterdam, Netherlands).

Genetic analysis: Phred scores of their nucleotide bases were checked, and forward and reverse sequences were assembled and then trimmed to remove MH3/MH4.5 primers in Geneious R11 (Kearse et al., 2012). The assembled sequence was blasted in the GenBank database to examine the nucleotide similarity (Altschul et al., 1990). Obtained the rrnS data from GenBank were aligned by ClustalW in MEGA $X$ multiple sequence alignments (Kumar et al., 2018). Pairwise distances were estimated using the K2P model in MEGA X (Kumar et al., 2018).

\section{RESULTS}

Ascaridoid nematodes were morphologically identified as the third stage of Anisakis type I larvae. Some specimens of Anisakis larvae were classified as A. pegreffii by RFLP analyses with HhaI and HinfI enzymes as previously described by D'Amelio et al., (2000). The amplified $r r n S$ gene of $A$. pegreffii was produced $\sim 500 \mathrm{bp}$ in the PCR analyses. After DNA sequencing of $r r n S$ gene and trimmed to primers, the $491 \mathrm{bp}$ length products were obtained in the present study. There were no intraspecific nucleotide differences detected within $r r n S$ gene of three representatives. Therefore, the $r r n S$ sequence of one representative was submitted to GenBank was given the accession number: MT484284. Comparison of the rrnS sequence of $A$. pegreffii from the Aegean Sea (MT484284) had $100 \%$ sequence similarity with the $r r n S$ sequence of different A. pegreffii isolates (JX500050; Stenella coeruleoalba, Mediterranean Sea), (LC222461; Scomber 
japonicus, Japan Sea), (JQ900764; human, Italy), (MF140359; Conger myriaster, China), (MT312511, MT312512; Neophocaena asiaeorientalis, South Korea). The $r r n S$ sequence of $A$. pegreffii from the Aegean Sea (MT484284) was most similar to A. pegreffii (MT312513, MT312515-MT312518) (99.80\%), A. simplex (99.59\%, JN786323), A. simplex x A. pegreffii (99.37\%, AB831878), A. berlandi (A. simplex C) $(98.98 \%$, JX500049), A. ziphidarum (96.54\%, JX500053), A. nascettii (JX500054; 95.11\%), A. brevispiculata (JX500056; 93.89\%), A. physeteris (JX500055; 93.52), A. paggiae (JX500057; 93.27\%), and A. typica (MT395672; 91.11\%). Pairwise distance between the $r r n S$ sequence of $A$. pegreffii from the Aegean Sea (MT484284) with those for other isolates $r r n S$ sequences of A. pegreffii (MT312511-MT312518, JX500050) showed divergence levels ranging from 0.00 to $0.41 \%$.

\section{DISCUSSION}

Current investigation provides the first molecular data of the $r r n S$ gene of Anisakis pegreffii from the Turkish marine waters. To date, among ascaridoid nematodes, Hysterothylacium aduncum, H. fabri, A. typica, and Contracaecum overstreeti species from Turkish marine waters have been molecularly characterized based on mitochondrial rrnS gene (Pekmezci, 2019; Pekmezci \& Yardimci, 2019; Pekmezci \& Onuk, 2020; Simsek et al., 2021).

The mitochondrial $r r n S$ gene sequence of adult $A$. pegreffii was obtained from Stenella coeruleoalba in the Adriatic and Tyrrhenian Sea and firstly recorded in the GenBank under accession number JX500050 by Mattiucci et al., (2014). Here, we report the second record of $A$. pegreffii $r r n S$ sequence (MT484284) from Mediterranean Sea. However, there are eight unpublished data of $A$. pegreffii mitochondrial rrnS sequences (MT312511MT312518) from Neophocaena asiaeorientalis in the South Korean waters.

Until now, nine Anisakis species have been genetically confirmed different gene loci worldwide (Mattiucci et al., 2018). Among these species, A. berlandi (JX500049), A. pegreffii (JX500050), A. simplex (JX500051), A. typica (JX500052; MT395672) A. ziphidarum (JX500053), A. nascettii (JX500054), A. physeteris (JX500055), A. brevispiculata (JX500056), A. paggiae (JX500057), and A. simplex $\mathrm{x}$ A. pegreffii (AB831878, unpublished data) had genetically characterized for $r r n S$ gene, and their sequences were also recorded to GenBank (Mattiucci et al., 2014; Pekmezci \& Onuk, 2020). The BLASTn search showed that the rrnS sequence of $A$. pegreffii isolate herein exhibits ranged from $91.11 \%$ to $99.59 \%$ similarity to those of $r r n S$ sequences of different Anisakis species (Mattiucci et al., 2014; Pekmezci \& Onuk, 2020). Therefore, the mitochondrial $r r n S$ gene can be used to differentiate among Anisakis species. Moreover, the genetic distance between our $r r n S$ sequence of A. pegreffii (MT484284) and other isolates $r r n S$ sequences of A. pegreffii (MT312511-MT312518) from South Korean waters was $0.41 \%$. The genetic difference between two isolates belonging to the same species may be related to the isolates being obtained from different geographic areas far from each other.

\section{CONCLUSION}

Herein, the novel data of mitochondrial small ribosomal subunit RNA sequence of $A$. pegreffii from Turkish marine waters was achieved for the first time, and this novel $r r n S$ data (MT484284) is a second data recorded in GenBank for A. pegreffii from the Mediterranean Sea. Furthermore, this novel $r r n S$ sequence can be utilized for genetic analysis of ascaridoid nematodes from the Mediterranean Sea.

\section{CONFLICT OF INTEREST}

The author declares that they have no competing interests.

\section{REFERENCES}

Altschul, S.F., Gish, W., Miller, W., Myers, E.W. \& Lipman, D.J. (1990). Basic local alignment search tool. Journal of Molecular Biology, 215, 403-410. DOI: $10.1016 / \mathrm{S} 0022-2836(05) 80360-2$

Berland, B. (1961). Nematodes from some Norwegian marine fishes. Sarsia, 2, 1-50.

D'Amelio, S., Barros, N.B., Ingrosso, S., Fauquier, D.A., Russo, R. \& Paggi L. (2007). Genetic characterization of members of the genus Contracaecum (Nematoda: Anisakidae) from fish-eating birds from west-central Florida, USA, with evidence of new species. Parasitology, 134, 1041-1051. DOI: 10.1017/S003118200700251X

D'Amelio, S., Mathiopoulos, K. D., Santos, C.P., Pugachev, O.N., Webb, S.C., Picanço, M. \& Paggi, L. (2000). Genetic markers in ribosomal DNA for the identification of members of the genus Anisakis (Nematoda: Ascaridoidea) defined by polymerase-chain-reaction-based restriction fragment length polymorphism. International Journal for Parasitology, 30(2), 223-226. DOI: 10.1016/s0020-7519(99)00178-2

Kearse, M., Moir, R., Wilson, A., Stones-Havas, S., Cheung, M., Sturrock, S., Buxton, S., Cooper, A., Markowitz, S., Duran, C., Thierer, T., Ashton, B., Meintjes, P. \& Drummond, A. (2012). Geneious Basic: An integrated and extendable desktop software platform for the 
organization and analysis of sequence data. Bioinformatics, 28(12), 1647-1649.

Kumar, S., Stecher, G., Li, M., Knyaz, C. \& Tamura, K. (2018). MEGA X: Molecular evolutionary genetics analysis across computing platforms. Molecular Biology Evoluation, 35, 1547-1549. DOI: $10.1093 / \mathrm{molbev} / \mathrm{msy} 096$

Mattiucci, S. \& Nascetti, G. (2008). Advances and trends in the molecular systematics of anisakid nematodes, with implications for their evolutionary ecology and host-parasite coevolutionary processes. Advances in Parasitology, 66, 47-148. DOI: 10.1016/S0065308X(08)00202-9

Mattiucci, S., Cipriani, P., Levsen, A., Paoletti, M. \& Nascetti, G. (2018). Molecular epidemiology of Anisakis and Anisakiasis: an ecological and evolutionary road map. Advances in Parasitology, 9, 93-263. DOI: 10.1016/bs.apar.2017.12.001

Mattiucci, S., Cipriani, P., Webb, S. C., Paoletti, M., Marcer, F., Bellisario, B., Gibson, D. \& Nascetti, G. (2014). Genetic and morphological approaches distinguish the three sibling species of the Anisakis simplex species complex, with a species designation as Anisakis berlandi n. sp. for A. simplex sp. C (Nematoda: Anisakidae). Journal of Parasitology, 100, 199-214. DOI: 10.1645/12120.1

Pekmezci, G.Z. \& Yardimci, B. (2019). On the occurrence and molecular identification of Contracaecum larvae (Nematoda: Anisakidae) in Mugil cephalus from Turkish waters. Parasitology Research, 118(5), 1393-1402. DOI: 10.1007/s00436-019-06278-x

Pekmezci, G.Z. \& Onuk, E.E. (2020). Molecular characterization of Anisakis typica (Nematoda: Anisakidae) from the Mediterranean Sea coasts of Turkey: First mitochondrial $r r n S$ sequence data. Journal of Anatolian Environmental and Animal Sciences, 5(2), 241-244. DOI: $10.35229 /$ jaes. 738822

Pekmezci, G.Z. (2019). Molecular characterization of Hysterothylacium aduncum (Nematoda: Raphidascarididae) larvae infecting Merlangius merlangus euxinus (Linnaeus, 1758) from the Turkish Black Sea coast based on mitochondrial small subunit ribosomal RNA gene analysis. Etlik Veteriner Mikrobiyoloji Dergisi, 30(1), 64-69. DOI: $10.35864 /$ evmd.562427

Pekmezci, G.Z., Onuk, E.E., Bolukbas, C.S., Yardimci, B., Gurler, A.T., Acici, M. \& Umur, S. (2014). Molecular identification of Anisakis species (Nematoda: Anisakidae) from marine fishes collected in Turkish waters. Veterinary Parasitology, 201, 82-94. DOI: 10.1016/j.vetpar.2014.01.005

Peter, A.J. \& Maillard, C. (1988). Larves d'ascarides parasites de poisons en Mediterranee occidentale. Bulletin du Museum National d'histoire Naturelle, 10 (Sect. A), 347-369.
Simsek, E., Sürsal, N., Karademir, G.K. \& Pekmezci, G.Z. (2021). First molecular characterization of Hysterothylacium fabri larvae (Nematoda: Raphidascarididae) in the Mediterranean Sea based on the small subunit ribosomal RNA gene sequence. Kocatepe Veterinary Journal, 14(1), 71-76. DOI: 10.30607/kvj.832003

Zhu, X., Gasser, R.B., Podolska, M. \& Chilton, N.B. (1998). Characterization of anisakid nematodes with zoonotic potential by nuclear ribosomal DNA sequences. International Journal for Parasitology, 28, 1911-1921. DOI: 10.1016/s0020-7519(98)00150-7 